\title{
"Ne Evet Ne Hayır!" Örneğinden Hareketle İmla ve Noktalama Kurallarının Edebî Metinlerle Öğretimi
}

\author{
İbrahim GÜLTEKIN*
}

Öz

İmla ve noktalama birbirini tamamlayan, yazıyı anlaşılır kılan iki temel ögedir. Okul dönemi ile birlikte imla ve noktalama kuralları kademeli bir şekilde öğrenciye kazandırılmaya çalışılmakta ve bu kuralları öğrencinin sadece okulda değil, yaşamı boyunca yazılı üretimlerinde kullanması hedeflenmektedir. Ancak konuyla ilgili yapılan araştırmalarda öğrencilerin her kademede imla ve noktalamaya ilişkin eksikliklerinin olduğunu ifade edilmektedir. Bu çalışmada noktalama işaretlerinin kullanımının ve imla kurallarının işlevsel öğretimine yönelik bağlam temelli bir öğretim yapılması gerektiği düşüncesi Oğuz Atay’ın 'Ne evet ne hayır!" hikâyesi ile örneklendirilmektedir. Oğuz Atay 70'li yıllarda Türk edebiyatına roman ve hikâyeleriyle katkı sunmuş önemli bir yazardır. Söz konusu hikâyesinde yanlış kullanımlar vasıtasıyla imla ve noktalamanın ehemmiyetini okura göstermektedir. İmla ve noktalamanın yazı için öneminin bir metin içerisinde vurgulandığ 1 tipik bir örnek olan "Ne evet ne hayır!" adlı eserde büyük harf kullanımı, alıntı kelimelerin yazımı, nokta, soru işareti gibi yazılan cümlelerin daha anlaşılır olmasını sağlayan yazının destekleyici unsurlarının kullanımı, yanlış kullanımı veya kullanılmayışları belirlenerek Türkçe yazma becerisinin kazandırılması ve geliştirilmesi sırasında doğru ve güzel yazma hedefi için metin odaklı öğretim konusunda bir bakış açısı sunmak amaçlanmaktadır.

Anahtar Kelimeler: Ana dili eğitimi, yazma becerisi, imla ve noktalama kuralları, imla ve noktalama kurallarının öğretimi, Oğuz Atay, Ne Evet Ne Hayır

\footnotetext{
* Doç. Dr., Kırıkkale Üniversitesi, Türkçe Eğitimi Ana Bilim Dalı, Kırıkkale, Türkiye.

Elmek: ibogultekin2000@yahoo.com

https://orcid.org/ 0000-0002-6084-7129
} 


\title{
Teaching spelling and panctuation through literary texts considering the example of "neither yes nor no".
}

\begin{abstract}
Spelling and punctuation are two basic elements that complement each other and make the text understandable. With the beginning of the formal schooling, spelling and punctuation rules are tried to be gradually imparted to students and it is aimed to enable them to use these rules not only in the school but also in their written productions throughout their lives. However, in the research on the subject, it is stated that students have deficiencies related to spelling and punctuation at all levels. In the current study, the concept that context-based teaching should be adopted for the functional teaching of spelling and punctuation rules was shown through the story "Ne evet ne hayır" written by Oğuz Atay, who is an important author that contributed to the Turkish Literature with his novels and stories in the 1970s. He shows the importance of the use of spelling and punctuation rules to the reader in this story. As a typical example in which the importance of spelling and punctuation is strongly emphasized, the story "Ne evet ne hayır!" was used to show the accurate, inaccurate use or absence of the complementary elements of any writing used to make writing more comprehensible such as the use of capital letters, writing of foreign words, use of full stop, question mark, dash, paragraphing, and thus it is aimed to present a perspective of text-centered teaching to accomplish the objective of accurate and nice writing while imparting and developing the writing skill in Turkish.
\end{abstract}

Keywords: Mother tongue teaching, writing skills, spelling and punctuation rules, teaching of spelling and punctuation rules, Oğuz Atay, Ne Evet Ne Hayır 


\section{Extended Summary}

Expression occurs through the use of speaking and writing skills. People sometimes complain that they cannot express their feelings and thoughts, opinions and impressions as they wish. Speaking is seen as a skill that the person expresses himself/herself more easily because it allows using compensatory strategies instantly compared to writing. Writing is described as the most difficult among language skills since self-expression through writing requires attention to many rules. Spelling and punctuation rules are among the rules that the individual should pay attention to while writing. With the beginning of the formal schooling, spelling and punctuation rules are tried to be gradually imparted to students and it is aimed to enable them to use these rules not only in the school but also in their written productions throughout their lives. However, the existence of incomplete learning in terms of using spelling and punctuation rules in practice has been revealed by the research. Although many factors may have contributed to the emergence of this problem, the main reason is said to be the rote learning-based teaching of spelling and punctuation rules.

In this regard, the purpose of the current study is to present an example of how to teach spelling and punctuation rules within a context; that is, in a textcentred way and to raise the awareness of the teaching of spelling and punctuation rules.

\section{Method}

In the current study, the document analysis method, one of the qualitative research methods, was employed. In the document analysis method, the existing notes and documents are examined to collect data (Karasar, 2006). This method was preferred in the current study to analyze the story "Ne evet ne hayır" by Oğuz Atay in terms of teaching spelling and punctuation rules. 


\section{Study Group}

The study group of the current research is the story "Ne evet ne hayır" from the book "Korkuyu Beklerken" by Oğuz Atay (1987), which is a typical literary text in terms of punctuation rules.

\section{Data Analysis}

The collected data were analyzed by using the descriptive analysis technique. The story "Ne evet ne hayır!" was analyzed to exemplify that literary texts can be used to teach spelling and punctuation rules.

\section{Findings}

It was seen that there are examples to be used to show how capital letters are used and barrowed words are written. The author used the lower cases for the initial letters in the name of the story on purpose "Ne evet ne hayir" so he wanted to draw attention to the use of capital letters on the basis of an inaccurate example. There are six basic rules defined in the Turkish spelling guidelines in relation to the use of barrowed words. When the barrowed words used in the story were examined, it was seen that there are examples not in compliance with these six rules.

In the story, in terms of punctuation rules, the use of full stop, comma, dash, quotation marks, circumflex, apostrophe and question mark are emphasized. In the examples given, it is seen that there are mistakes stemming from the inaccurate/incomplete use of punctuation marks or absence of them.

The findings obtained have revealed that there are six examples about the use of capital letters and two examples about the writing of barrowed words. In relation to punctuation, in the text there are 2 examples about the use of full stop, 1 example about the use of dash, 1 example about the use of circumflex, 1 example about the use of question mark and 1 example about the use of question mark; thus, there are a total of 10 examples about punctuation.

In addition to the findings obtained in relation to spelling and punctuation in the text, emphasis is also put on figural characteristics of any writing such as paragraphing. 


\section{Results and Discussion}

It is seen that a lot of research has been done about how to make students internalize spelling and punctuation and to use them correctly in texts. In the current study, it was aimed to exemplify that literary texts could be used to enable students to understand the functioning of spelling and punctuation rules. To this end, it was thought that the story "Ne evet ne hayır!" by Oğuz Atay would provide a typical example of how to use literary texts to increase awareness of spelling and punctuation rules in students. When the target audience of this text is considered, it can be said that the story "Ne evet ne hayir" is suitable for high school students or college students in terms of teaching spelling and punctuation rules. However, the correct use of spelling and punctuation is an issue that is emphasized as of primary school. It is believed that presentation of information about spelling and punctuation through the possibilities offered by literature/children's literature to children would be useful considering their ages and developmental characteristics. Only in this way will it be possible to functionally teach the logic behind spelling and punctuation rules to students. Other studies in the literature also support this view (Kalfa and Avc1 2020; Atasoy 2017; Adıgüzel 2014; Kalfa 2002).

Though spelling and punctuation knowledge is related to the writing skill, they are also closely associated with other skills particularly reading. In a reading text, punctuation in the sense making process carried out within the author-text-reader triangle is an important element leading the reader to comprehension. The same also holds true for the process of making sense during listening. For a speaker to use stress and tone in proper places, he/she needs to have information about the correct use of punctuation marks.

Literary works serve the function of a guideline in the purification and deepening of the pleasure taken from language as they present the examples of the most beautiful use of a language. In the current study, necessity and sensitivity of using spelling and punctuation rules are emphasized on a story text. 



\section{Giriş}

Anlatma, konuşma ve yazma becerilerinin kullanımı ile gerçekleşmektedir. İnsanlar kimi zaman duygu ve düşüncelerini, görüş ve izlenimlerini istediği gibi anlatamadığından yakınmaktadır. Konuşma, yazmaya nazaran telafi stratejilerini anında kullanmaya imkân sağladığı için kişinin kendini daha rahat ifade ettiği beceri olarak görülmektedir. Yazarak kendini anlatma, birçok kurala dikkat etmeyi de beraberinde getirdiğinden yazma dil becerileri arasında en zoru olarak nitelendirilmektedir. Bunun sebebini, Maltepe (2006:56) süreçte psikolojik, dilbilgisel ve bilişsel sorunlar yaşanmasıyla açıklarken Tiryaki (2013) yazmanın; kişinin dünya bilgisi, konuyu kavrama düzeyi, sunma düzeni, yazma amacı gibi karmaş1k ve birbirini takip etmek durumunda kalan bir zihinsel sürece tabi olmasına bağlamaktadır. Güneş (2007), bu süreci, zihin yapısını düzenleyen işlemler olarak adlandırmaktadır.

Okulla birlikte edinme süreci başlayan yazma becerisindeki başarı için öğrencinin dinleme, konuşma ve okuma becerilerinde yetkinlik kazanmış olması beklenmektedir. Yazma beyinde yapılandırılmış bilgilerin yazıya dökülmesi işlemidir, bunun için öğrencilerin dinledikleriyle okuduklarını iyi anlamaları gerekmektedir (MEB, 2005: 22). Bu bağlamda yazma düşünceyi kalıcı kılma, sözü çevrenin sınırları dışına taşıma demektir (Özdemir, 1994). Ülper'e (2012:123) göre bir yazılı metin üretebilmek için metnin dilbilgisel, işlevsel ve üslupsal yönlerine odaklanmak gerekmektedir. Buna bağlı olarak yazının bağdaşıklık özellikleri, yazım, noktalama, bakımından yetkin olması; tutarlılık özellikleri açısından da metnin sorunsuz olması beklenmektedir.

Oluşturulan yazılı metin öğrencinin ilgili konudaki bilgisini, yaşayışını, anlayışını, zihinsel düzeyini, kelime dağarcığını ve anlatım gücünü yansıtmaktadır (Göğüş, 1978). Yazma becerisi üzerine yapılan çalışmalarda öğrencilerin birçoğunun beceriyi sınırlı düzeyde gerçekleştirebildiği (Hamzadayı ve Çetinkaya, 2013), okullarda yazmaya ayrılan vaktin az olduğu ve öğrencilerin bu çalışmalara etkin 
katılım göstermediği (Alpaslan, 2001), yazma etkinliklerinin ve buna yönelik değerlendirme çalışmalarının sınırlılığı (Durukafa, 1992), yazılı üretime yönelik geribildirimlerin yetersizliği (Karatay, 2011), kullanılan yöntemlerin işlevsel ele alınmadığı (Topuzkanamış, 2014), lisans programları ile öğretim programlarında ifade edilen kazanımların istenen düzeyde gerçekleşmediği, imla ve noktalama kurallarına dikkat edilmediği (Arıcı ve Ungan, 2008; Çelik, 2010; Bağc1, 2012; Can, 2012) ifade edilmektedir. Tağa ve Ünlü (2013) de günümüzde cep telefonları ve sanal ortamlarda kullanılan dilin, yazıya/yazılı üretime olumsuz yansıdı̆̆ını belirtmektedir. Zikredilen son tespitin doğru, verilen hükmün isabetli olmadığ söylenebilir. Cep telefonları ve sanal ortamlarda kullanılan dilin "yazıya olumsuz yansıması" ifadesi başka mecralarda doğru ve kurallı bir kullanımın olduğunu zımnen ifade etmektedir ki daha önce konuyla ilgili belirtilen araştırmalarda vurgulanan görüşlerle bu durum çelişmektedir.

Bir dil becerisi olarak yazma, doğuştan getirilen bir yetenek değil eğitim yoluyla edinilen ve geliştirilen bir beceridir (Sever, Kaya ve Aslan, 2006). Öğrencinin beceriyi edinmesi, geliştirmesi ve hayatı boyunca kullanacağı bir alışkanlığa dönüştürmesi için yeterince yazma etkinliği yapması sağlanmalı ve bu yazma görevlerine ilişkin sağlıklı geribildirimlerde bulunulmalıdır. Okullardaki süreç dikkate alındığında yazma becerisine ilişkin sınıf ortamında yapılan etkinliklerin sınırlı olduğu, öğretmenlerin geribildirim noktasında yazmanın dış yapı unsurlarına yoğunlaştığı bilinmektedir (Karatay, 2011; Akmugan, 2019). Ülper (2012) yazmanın dış yapı özelliklerini; imla, noktalama, paragraflara ayırma şeklinde ifade etmektedir. Her ne kadar yazma etkinliklerinin değerlendirilmesinde yazmanın dış yapı unsurları öncelense de yapılan araştırmalarda öğrencilerin imla ve noktalama açısından istenilen düzeyde olmadığ 2006; Erdem, 2007; Karagül, 2010; Özkara ve İzci, 2013). Oysa imla ve noktalama yazıyı anlaşılır kılan temel unsurlar olarak değerlendirilmektedir. Maden (2013) de yazma sürecinde uyulması zorunlu olan imla ve noktalama kurallarının; anlatılanın hem biçim hem içerik açısından doğru, etkili ve anlaşılır olmasını sağladığını belirtmektedir. 


\section{İmla ve Noktalama}

İmla ve noktalama birbirini tamamlayan, yazıyı anlaşılır kılan iki temel ögedir. $\mathrm{Bu}$ anlamda yazılı bir metnin başarısını belirleyen unsurlardan olduğu ve metni tamamlayıcı bir nitelik sergilediği söylenebilir (Karakaş ve Akın, 2018:648). İmla ve noktalamaya dair kurallar, İmla Kılavuzu veya Yazım K1lavuzu adlı başvuru kitaplarında yer almaktadır. İlgili alanyazın incelendiğinde farklı yazım/imla kılavuzlarının varlığı dikkat çekmektedir (Türk Dil Kurumu, Dil Derneği, Kubbealtı gibi) ancak öğretimde ve resmî yazışmalarda mecbur tutulanın Türk Dil Kurumu tarafından hazırlanan Yazım Kılavuzu (2012) olduğunu söylemek mümkündür.

Okul dönemi ile birlikte imla ve noktalama kuralları kademeli bir şekilde öğrenciye kazandırılmaya çalışılmakta ve bu kuralları öğrencinin sadece okulda değil hayatı boyunca yazılı üretimlerinde kullanması hedeflenmektedir. Maden ve Maden (2018: 381), okulun ilk yıllarından itibaren yazılı anlatım sürecinde çocuğa imla kılavuzundaki kuralları esas almasının öğretilmesi ve bunu bir alışkanlık hâline dönüştürmesi için öncelikle öğretmenin kılavuzu kullanma beceri ve alışkanlığına sahip olması gerektiğini ifade etmektedir. Öğretmen, doğru yazma becerisinin imla kılavuzu kullanma ile pekişeceği noktasında öğrencilere rol model olabilmelidir. Elbette öğretmenin, öğrenciye rol model olması, kılavuzun nasıl kullanılacağına ilişkin rehberlikte bulunması bu anlamda önemlidir. Erkınay (2011), bir cihazın nasıl çalıştırılacağına ilişkin ürünle birlikte sunulan kullanım kılavuzunun doğru ve verimli kullanma sürecine sağladığı ciddi katkının benzeri bir işlevi etkili yazma için imla kılavuzunun üstlendiğini ifade etmektedir.

İmla kılavuzları, yazım ve noktalama işaretlerinin kullanımına ilişkin verdiği bilgiyle iki ana bölümden oluşmaktadır. Yazım kısaca bir dili yazıya geçirmek için oluşturulan kurallar (Türkçe Sözlük, 2005) olarak tanımlanmaktadır. Alanyazında konuyla ilgili farklı tanımlamalar da dikkat çekmektedir. Yazım; doğru anlamayı kolaylaştırmak için sözlü anlatımda ses, dizim, anlam, önerme ve söz dışı göstergelere yüklenen ayrımların yazılı metinde görselleştirilmesi (Demircan, 2001:11), bir dilin söz varlığını o dilde yürürlükte olan ses, şekil, köken vb. kurallara uygun olarak yazıya geçirme; dildeki sözleri kurallarına uygun olarak yazma (Korkmaz, 2007:130), bir dilin kelimelerinin doğru bir şekilde yazıya 
geçirilmesini sağlayan ortak yazma biçimi (Kavcar, Oğuzkan ve Aksoy 2002:50) şeklinde açıklanmaktadır. Yapılan tanımlar dikkate alındığında yazımla yazıda ortaklığı sağlayan kurallar bütününün kastedildiği anlaşılmaktadır.

Yazım kuralları, uyulması gereken kurallardır ve yazı dilinin, aynı kod sistemini kullanan insanlarca doğru anlaşılabilmesini sağlamaktadır. Karakaş ve Akın (2018: 648), yazım kurallarının yazıya ait bir dış yapı unsuru gibi görünmesine rağmen anlamı etkilemesi, değiştirmesi ve düzeltmesi gibi işlevler üstlenmesiyle yazının iç unsuruna dönüştüğünü belirtmektedir. Türkçenin yazımına ilişkin kuralların ne olduğuna yönelik bilgi Yazım Kılavuzu'nda (TDK, 2012);

- Bazı kelime ve eklerin yazılışı (soru edatı "mI"nın yazılışı; bağlaç olan "da, de"nin, "ki”nin "ile"nin, bulunma hâli eki “+DA"nın, mastarlara gelen eklerin, ek fiilin, pekiştirmeli sözlerin yazılışı ve fiil çekimi ile ilgili yazılışlar),

- Sayıların yazılışı,

- Büyük harflerin kullanıldığı yerler,

- Birleşik kelimelerin yazılışı (bitişik yazılan birleşik kelimeler, ayrı yazılan birleşik kelimeler, deyimlerin yazılışı, ikilemelerin yazılışı),

- Alıntı kelimelerin yazılışı,

- Yabancı özel adların yazılışı (Latin harflerini kullanan dillerdeki özel adlar, Arapça ve Farsça özel adlar, Yunanca özel adlar, Rusça özel adlar, Uzak Doğu dillerindeki özel adlar, Türk devletleri ve topluluklarındaki özel adlar),

- Kısaltmalar şeklinde sıralanmaktadır. Yazım Kılavuzu'nda ayrı bir madde başı olarak değerlendirilmemekle birlikte ses hadiselerinden kaynaklanan yazım özelliklerine de dikkat çekilmektedir. Görüldüğü gibi yazıma ilişkin birçok kural bulunmaktadır, bu kuralların sunulmasının ezberden ziyade metin odaklı öğretimin kalıcılı̆ğ artırmada etkili olacağı düşünülmektedir. İmla kılavuzunun bir diğer temel ögesi, noktalama işaretleridir. Yazım Kllavuzu (TDK 2012: 27), noktalama işaretlerinin işlevini, "Duygu ve düşünceleri daha açı ifade etmek, cümlenin yapısını ve duraklama noktalarını belirlemek, okumayı ve anlamayı kolaylaştırmak, sözün vurgu ve ton gibi özelliklerini belirt- 
mek üzere noktalama işaretleri kullanılır.” şeklinde açıklamaktadır. Banguoğlu da (1998:129) sözün boğum noktalarını, bazı vurgu ve durakları, cümle çeşitlerini göstermek amacıyla noktalama işaretlerinden faydalanıldığını dile getirmektedir. $\mathrm{Bu}$ anlamda doğru ve etkili konuşmayı sağlayan vurgu, tonlama, durak gibi kavramların bir bölümünün yazıda noktalama işaretleriyle karşılandığı söylenebilir (Beyreli, Çetindağ ve Celepoğlu 2005). Yazıda kullanılan noktalama işaretleri, konuşmayı destekleyen vurgu, tonlama, jest ve mimikler gibi özelliklerin yazıya aktarılmasına olabildiğince yardım eden araçlardır. Olabildiğince denmesinin sebebi parçalar üstü ses birimlerinin (ton, ezgi gibi özellikler) yazıda bütünüyle gösterilememesidir (Atasoy, 2017).

Noktalama işaretlerinin ihtiyaç duyulan yerde uygun biçimde kullanılması, sadece biçime değil, içeriğe de hizmet etmektedir (Maden 2013:32). Kantemir (1991), noktalama işaretlerinin yazıda kullanılmaması durumunda anlamın karanlıklar içerisinde kaybolacağını dile getirmektedir. Böyle bir kanının gerekçesi, bazı noktalama işaretlerinin anlam değeri taşımasıyla açılanabilir. Ağca'ya (1999: 97) göre ünlem, soru işareti, virgül içinde bulundukları cümleleri anlam yönünden düzenlemekte, aynı zamanda cümlenin vurgusunu belirlemede önemli bir işlev yüklenmektedir. Böylece noktalama işaretleri sadece yazma becerisinin değil, okuma becerisinin de temel unsuruna dönüşmektedir. Kavcar, Oğuzkan ve Sever (2004) de bu işaretlerin yazıda bütünlüğün oluşmasına katkı sağladığını belirterek yazılı iletişimi sağlıklı hâle getirdiğini ifade etmektedir.

Türkçe yazı diline ait 17 noktalama işareti bulunmaktadır. Bunlar; nokta, virgül, noktalı virgül, iki nokta, üç nokta, soru işareti, ünlem işareti, kısa çizgi, uzun çizgi, eğik çizgi, ters eğik çizgi, tırnak işareti, tek tırnak işareti, denden işareti, yay ayraç, köşeli ayraç ve kesme işaretidir (TDK 2012). Ayrıca seslerle ilgili bölümde düzeltme işareti de verilmektedir. Sıralanan noktalama işaretlerine yönelik sunulan kuralların oldukça ayrıntılı ifade edildiği dile getirilebilir. Noktalama işaretlerinin öğretimine yönelik ilkokuldan yükseköğretime kadar her kademede öğrenciye bir içerik sunulmaktadır. Ancak belirtilen kuralların istenen düzeyde edinilmediği yapılan araştırmalarda ortaya konmaktadır (Avc1 2006; Karagül 2010). Kalfa ve Avc1 (2020:132), öğrencilerin noktalama işaretlerine, kendilerini yazılı anlatımda doğru bir şekilde ifade etmek için değil, sınavda ilgili yere hangi 
noktalama işaretinin getirilebileceği veya getirilemeyeceği kararını verme noktasında ihtiyaç duyduğunu; bir bakıma, öğrencinin noktalama işareti kullanımından çok nerelerde zorunlu olarak kullanılması gerektiğini bilmeye odaklandığını vurgulamaktadır.

Noktalama işaretlerinin yanlış kullanımı, cümlelerde anlam kaymasına sebep olurken (Hatiboğlu 2003) hiç kullanılmaması ise anlamı belirsizleştirmektedir. Yanlış, eksik kullanılması veya hiç kullanılmaması gibi yaygın görülen noktalama hatalarının nedenini Atasoy (2009), şu şekilde sıralamaktadır:

- Noktalama kurallarını önemsememe

- Noktalama kurallarına neden ihtiyaç duyulduğuna yönelik bir farkındalık oluşturamama

- Noktalama kurallarının öğretimine ilişkin örneklerin özensiz seçimi

- Noktalama işaretlerini pekiştirmek üzere verilen örneklerde görülen noktalama hataları

- Noktalama kurallarının sadece sınavda çıkacak soruları yapabilmek için gerekli olduğuna dair yaygın yanlış kanı

- İhtiyaç olmayan durumlarda gereksiz noktalama işareti kullanımı

Belirtilen hususlar göz önünde bulundurulduğunda sorunun kaynağının noktalama işaretlerine gereken önemin verilmemesi ve bu işaretlere yönelik kuralların işlevsel öğretilmemesinden kaynaklandığını söylemek mümkündür. $Y a-$ zım Kılavuzu (2012), kuralları örnek cümleler vererek sıralamaktadır. Kılavuz bir başvuru kitabıdır, bir öğretim materyali değildir. Dolayısıyla imla ve noktalama kurallarının öğretiminde kılavuzun aynen yazdırılması veya yer alan kuralların ezberletilmesi yoluna gidilmemelidir. Böyle bir öğretimin fayda sağlamayacağ ortadadır.

Kılavuzdan yararlanacakların öncelikle yazım ve noktalamaya ilişkin kuralların kullanım mantığını çözmesi, bir başka ifadeyle neden kılavuzda bu kurallara yer verildiğini anlaması gerekmektedir (Atasoy 2017). Dolayısıyla kılavuzda yer alan kuralların kullanımı müstakil bir konu olmaktan ziyade cümle bilgisinden hareketle öğretilebilecek bir konudur (Kalfa ve Avc1 2020: 132). Kılavuzun sadece kurallarıyla değil, kurallar altında yer alan örnekleriyle de kılavuzluk yap- 
ması beklenmektedir bu nedenle kuralların öğretimi metinlere dayandırılmalıdır (Adıgüzel 2004). Kalfa (2000), sorunun çözümüne yönelik imla ve noktalamanın, ilkokuldan başlanarak aşama aşama cümleyle birlikte onun bir parçası olarak öğretilmesi, metni tamamlayıcı bir nitelik taşıdığının vurgulanması gerektiğini söylemektedir. $\mathrm{Bu}$ anlamda imla ve noktalamaya ilişkin kuralların bağlam, bir başka ifade ile metin odaklı nasıl verilebileceğine ilişkin bir örnek sunmak, konunun öğretimine ilişkin farkındalık geliştirmek bu çalışmanın amacını teşkil etmektedir.

\section{Yöntem}

Çalışmada, nitel araştırma yöntemlerinden biri olan belgesel tarama kullanılmıştır. Belgesel tarama, doğrudan görüşme ve gözlem imkânının bulunmadığı şartlarda işe koşulmaktadır (Yıldırım ve Şimşek 2011). Belgesel taramada var olan kayıt ve belgeler incelenerek veri toplanmaktadır (Karasar, 2006). Bu çalı̧̧mada Oğuz Atay’ın “Ne evet ne hayır!” adlı hikâyesini, imla ve noktalama kurallarının öğretimi açısından çözümlemek amacıyla bu yöntem tercih edilmiştir.

Oğuz Atay'ın Korkuyu Beklerken (1987) kitabında yer alan, noktalama kuralları açısından tipik bir edebî metin olma özelliği taşıyan "Ne evet ne hayır!" adlı hikâyesinin içeriği şu şekilde özetlenebilir.

İki tutunamayan karakter bir mektup vasıtasıyla birleşir. Arkadaşları tarafından zaman zaman "manyak" sıfatıyla hitap edilen ve sigorta memurluğu, havagazı tahsildarlığı, ilaç satıcılığı ve reklamcılık gibi sıkıcı mesleklere girip çıkan kahraman anlatıcı Dr. Akın Korkmaz; lise mezunudur ve yeni başladığı gazetenin "Gönül Postası" köşesinde insanların dertlerine ruhbilim kitapları okuyarak çözüm bulmaya çalışmaktadır. Kendisine gelen mektuptaki M.C. rumuzlu şahıs ise yirmi dört yaşında, uzun boylu, esmer bir gençtir; liseye iki yıl devam eder, hiçbir işte tutunamaz. Çok sevdiği bir kız vardır. Genç, sevdiği kıza onu sevdiğini söyler fakat kız, M.C.'ye "Ne evet ne hayır!" der. M.C. de çareyi gazetenin "Gönül Postası" köşesine mektup yazmakta bulur. M.C. hikâyenin sonunda hapse düşer, ölmek ister. Yirmi dört yaşında olmasına rağmen saçları bembeyaz olur. Uğrunda bu hâllere düştügü kız ise başkasıyla nişanlanır. (Atay 2019: 301-302; Sakall 2011). 
Özetlenen metinde imla ve noktalamayla ilgili yazar kaynaklı ilk ifade üst metinde "Mektupta hemen hiç noktalama işareti yoktu." şeklindedir (Atay, 1987: 90). Üst anlatıda geçen bu cümle okuru alt metne, metinde noktalama işaretleriyle ilgili birtakım hadiselere hazırlamakta, nasıl bir metinle karşı karşıya kalacağına dair bir ipucu sunmakta, okunacak metnin noktalama işaretleri kullanılmadan yazılmış olduğu bilgisi okurun bilinçaltına, bir değersizlik göstergesi olarak yerleştirilmektedir. "Ne evet ne hayır!" metni bu anlamda imla ve noktalama açısından çalışılmaya uygun bulunmaktadır.

\section{Verilerin Analizi}

Veriler, betimsel çözümleme tekniği kullanılarak analiz edilmiştir. Bu tekniğe göre elde edilen veriler daha önceden belirlenen kategorilere göre özetlenmekte ve yorumlanmaktadır. Bunun için elde edilen bulgular, önce dizgesel ve açık bir biçimde betimlenmekte daha sonra bu betimlemeler açıklanıp yorumlanarak birtakım bulgu ve sonuçlara ulaşılmaktadır (Yıldırım ve Şimşek 2011). Ulaşılan bulgu ve sonuçları yansıtmak amacıyla çalışmada doğrudan alıntılara sık sık yer verilmektedir. "Ne evet ne hayır!" adlı hikâye imla ve noktalama kurallarının öğretimi bağlamında edebî metinlerin kullanılabileceğini örneklemek maksadıyla çözümlenmiştir. Eser, araştırmacı dışında üç alan uzmanı tarafından da okunmuş ve hikâyede geçen imla ve noktalamaya yönelik ifadeler alan uzmanlarınca fişlenmiştir. Daha sonra araştırmacı ve alan uzmanları bir araya gelerek belirledikleri ifadeleri karşılaştırmış, farklı tespitlere yönelik ilgili bölümler yeniden gözden geçirilmiştir. Görüş birliği sağlanan ifadeler, bulgular bölümüne aynen taşınmış böylece nitel araştırmanın doğasına özgü geçerlik ve güvenirlik sağlanmaya çalışılmıştır (Arastaman, Fidan ve Fidan 2018).

\section{Bulgular}

"Ne evet ne hayır!" adlı hikâye, imla ve noktalama kurallarının öğretimi bağlamında edebî metinlerin kullanımını örneklemek amacıyla incelenmiş, eserde geçen imla ve noktalamaya ilişkin ifadeler, alıntı cümlelerle örneklenmiştir. Buna göre elde edilen bulgular, şu şekilde ifade edilebilir. 
Tablo 1. Imlaya İlişkin Bulgular

\begin{tabular}{|c|c|}
\hline İmla Kuralı & Alıntı Yapılan İfade \\
\hline \multirow{6}{*}{$\begin{array}{c}\text { Büyük } \\
\text { harflerin } \\
\text { kullanımı }\end{array}$} & NE EVET NE HAYIR (büyük harfler benimdir) (Atay, 1987: 90) \\
\hline & $\begin{array}{l}\text { Oğlum, tercih hakkı kızımdadır, ben bir şey söyleyemem NE EVET NE } \\
\text { HAYIR dedi. (Büyük harfler benimdir.) (Atay, 1987:93) }\end{array}$ \\
\hline & $\begin{array}{l}\text { Ben seni öldüremem, sen beni öldürürsün. Seviyorum seni. Bana bir } \\
\text { EVET VEYA HAYIR (büyük harfler benimdir) (Atay, 1987:94) }\end{array}$ \\
\hline & $\begin{array}{l}\text { NE EVET NE HAYIR (büyük harfleri benim yazdığımı biliyorsunuz ar- } \\
\text { tık, neden yazdığımı da biliyorsunuz). (Atay, 1987:97) }\end{array}$ \\
\hline & $\begin{array}{l}\text { Ne istersen yapacağım. Ne olur konuş benimle, gençliğimize yazık. Ce- } \\
\text { vap vermedi: NE EVET NE HAYIR. (Atay, 1987:98) }\end{array}$ \\
\hline & Bugüne kadar EVET VEYA HAYIR (Atay, 1987:100) \\
\hline $\begin{array}{c}\text { Alıntı } \\
\text { kelimelerin } \\
\text { yazılışı }\end{array}$ & $\begin{array}{l}\text { Kalbim midem opdolidondan (optalidon) fazla miktarda aldığım için mi- } \\
\text { demi parçaladım efendim. (Atay 1987:91) }\end{array}$ \\
\hline
\end{tabular}

Tablo 1 incelendiğinde "Ne evet ne hayır!" adlı hikâyede imlaya yönelik büyük harf kullanımı ile alıntı kelimelerin yazımı hususunda örneklerin bulunduğu görülmektedir. Büyük harflerin kullanımına yönelik farkındalık, hikâyenin de adı olan "ne evet ne hayır” söz öbeği ile sağlanmaya çalışılmıştır. Yazım Kılavuzu'nda (2012) büyük harflerin nasıl yazılması gerektiğine yönelik yedi ana başlıkta detaylı açıklamalar bulunmaktadır. Ancak cümle içinde büyük harflerin tamamının büyük yazımına ilişkin bir kural bulunmamaktadır. Yazar, yanlış örnek üzerinden büyük harfin doğru yazımına dikkat çekmek istemiştir, denilebilir. Alıntı kelimelerin yazımı için kılavuzda altı kural belirtilmektedir. Hikâyedeki alıntı kelimeyi örnekleyen cümle incelendiğinde yazım yanlışı olan bir kullanımın söz konusu olduğu anlaşılmaktadır.

"Ne evet ne hayır!" noktalama işaretlerinin kullanımı açısından okuruna zengin bir malzeme sunmaktadır. Noktalama işaretlerinin kullanımına ilişkin ulaş1lan bulgular Tablo 2'de belirtilmektedir. 
Tablo 2. Noktalama İşaretlerine İlişkin Bulgular

\begin{tabular}{|c|c|}
\hline Noktalama İşareti & Alıntı Yapılan İfade \\
\hline Nokta & $\begin{array}{l}\text { Kaybedersem öldürürüm. Kendimi. Onu da. (Noktalamalar } \\
\text { M.C.'nindir.) (Atay, 1987:93) }\end{array}$ \\
\hline Virgül & $\begin{array}{l}\text { Bütün problemleri ele alarak uzun bir araştırmalardan en ince teferru- } \\
\text { atına kadar iğneden ipliğine kadar düşündüm ele aldım niyetimi gayet } \\
\text { ciddi kurdum (bazı yerlerde virgül koymak gerektiğini hissediyorum, } \\
\text { fakat nedense bunu yapmak elimden gelmiyor) (Atay, 1987:90) }\end{array}$ \\
\hline Uzun çizgi & $\begin{array}{l}\text { "Sevdiğim insanla } 1970 \text { yılında karşı karşıya geldik (birdenbire vu- } \\
\text { rulduğu tarihten üç yıl sonra). Bana NE EVET NE HAYIR (hay Allah } \\
\text { kahretsin!) cevap vermeyen insan «Ben sana haber gönderdim.» dedi. } \\
\text { «Kiminle acaba?» (Konuşma işaretleri benimdir.) Arkadaşlarımla. } \\
\text { (Nedense, konuşma işaretlerini kaldırmayı daha uygun buldum.) Bana } \\
\text { böyle bir şey söylenmedi, ben ağzınızdan dinlemek isterim. Böyle de- } \\
\text { dim. Cevabınız? dedim." (Atay, 1987: 91) }\end{array}$ \\
\hline & $\begin{array}{l}\text { "Evde her zaman çaldığım plağı, resmimi görüp okumuşlar ne yazmış- } \\
\text { sam: tabii "ölünceye kadar seveceğim seni”" diye (başka ne yazarsın } \\
\text { ki? Tırnak işaretleri benimdir)" (Atay, 1987:92) }\end{array}$ \\
\hline Tirnak işareti & $\begin{array}{l}\text { Tuttu bana, "Babamla ne konuştunuz?” (dedi, tırnak işaretleri benim- } \\
\text { dir.) (Atay, 1987:94) }\end{array}$ \\
\hline Düzeltme işareti & $\begin{array}{l}\text { Başını eğdi yere. Sustu. Cevap vermek yok. Hep susuyor, Hâlâ susuyor } \\
\text { (şapkalar benimdir) (Atay, 1987:95) }\end{array}$ \\
\hline Kesme işareti & $\begin{array}{l}5 \text { yıldır uyku nedir bilmem, yemek içmek bunu da bilmem, bir Allahım } \\
\text { bir ben varım. (Atay, 1987:99) }\end{array}$ \\
\hline Soru işareti & $\begin{array}{l}\text { Sevdiğim kızın annesinin yanında vücudumu çıkardım bak anneciğim } \\
\text { görüyor musun. Bu kesiklikleri. Ben. (Noktalama işaretleri onundur.) } \\
\text { (Atay, 1987:93) }\end{array}$ \\
\hline
\end{tabular}

Tablo 2'ye bakıldığında nokta, virgül, uzun çizgi, tırnak işareti, düzeltme işareti, kesme işareti ve soru işaretine metinde dikkat çekildiği görülmektedir. Verilen örneklerde noktalama işaretinin eksik/yanlış kullanılmasından veya hiç kullanılmamasından kaynaklı hataların varlığı dikkat çekmektedir. Cümlede noktanın gereksiz kullanımı söz konusuyken virgülün kullanılmamasından kaynaklı bir sorun dikkat çekmektedir. Virgülle ilgili "Sıralı cümleleri birbirinden ayırmak için konur." kuralının cümlede işlerlik kazanmadığı anlaşılmaktadır (TDK 2012). Diyaloğa dayalı durumlarda ifadelerin birbirine karışmaması için kullanılan uzun çizgi bir başka deyişle konuşma çizgisinin kullanılmaması kaynaklı bir anlam kargaşası söz konusudur. Tırnak işareti veya konuşma çizgisi kurmaca metinler- 
de konuşma ifadelerini ayrıt etmeye yarayan, metnin anlaşılmasını kolaylaştıran işaretlerdir. Dr. Akın Korkmaz, muhatap aldığı kişinin tanınması, bu kişinin gönderdiği ve gazetede yayımlamayı uygun gördüğü mektubun iyi anlaşılması için konuşma işaretlerinden faydalanmayı düşünmektedir. En azından metni kurgularken okurun zihninde böyle bir anlam oluşmasını beklemektedir.

Bir kelime arayla koyduğu ve kaldırdığı "konuşma işaretleri”nin varlığ 1 M.C. ile Dr. Akın Korkmaz’ı tutarsız davranışlar bakımından ortak kişilik özelliklerinde birleştirmektedir. Edebî eser okuyana verdiği estetik zevk dışında yazılı metin olarak dilin yazara özgü bütün kullanımlarını bir zenginlik olarak korumakta ve sonraki nesillere aktarmaktadır. Ayrıca bahse konu olan hikâyedeki gibi birtakım metin dışı işlevlere de ev sahipliği yapabilmektedir. Nitekim bu hikâyede sadece konuşma işaretlerinin kullanılması veya kullanılmaması üzerinden metni yazanların sahip olduğu görüntü, toplumda yaşayan fertlerin hiçbirinin içine düşmek istemeyecekleri bir durum oluvermiştir. Hikâyenin gerçek yazarı Oğuz Atay kurgusal yazarlarından birini (Dr. Akın Korkmaz) konuşma işaretlerini kullanıp kullanmama konusunda tereddüt içinde bırakarak ürkek, diğerini (M.C.) daha zavallı durumda gösterebilmektedir. Bu durum, bir noktalama işaretinin varlığı veya yokluğunun metindeki anlam oluşumunu ne derecede etkileyebildiğini göstermesi bakımından önemlidir.

Tek tırnak işaretinin kullanımına yönelik farkındalık yanlış kullanımla verilmektedir. Tek tırnak, tırnak içinde verilen cümlenin içinde yeniden tırnağa alınması gereken bir sözü, ibareyi belirtmek için kullanılmaktadır (TDK 2012). Örnek cümlede tek tırnak kullanılması gereken yerde tırnak işaretine yer verilerek bu kurala uymayan bir kullanımın olduğu görülmektedir. Düzeltme işaretine ilişkin cümlede doğru kullanım örneklenmektedir. "Özel adlara getirilen iyelik, hâl ve bildirme ekleri kesme işaretiyle ayrılır.” kuralı, kesme işaretine ilişkin en bilinen kuraldır ancak ulaşılan bulguda bu kuralın ihlali söz konusudur.

"Sevdiğim kızın annesinin yanında vücudumu çıkardım bak anneciğim görüyor musun. Bu kesiklikleri. Ben. (Noktalama işaretleri onundur.)” ifadesi birden fazla noktalama işaretinin kullanımı ile ilgili olmakla birlikte soru işaretinin kullanılmama durumunun baskın olduğu görülmektedir. Bunun yanı sıra cümlede nokta işaretinin kullanılmaması kaynaklı bir hata vardır.

Hikâyede "noktalama” kelimesi üç kez tekrarlanmaktadır: 
"Bă̆rım ateş gibi yandı (satırbaşı benimdir). Kaybedersem öldürürüm. Kendimi. Onu da. (Noktalamalar M.C.' nindir.) Sevdiğim kızın annesinin yanında vücudumu çıkardım bak anneciğim görüyor musun. Bu kesiklikleri. Ben. (Noktalama işaretleri onundur.) Baktı. (Önce)leri M.C.'nin hiç noktalama işareti kullanmadiğın saniyordum. Son okuyuşumda mektubun solmakta olan mürekkebine dikkatle baktığımda bu işaretleri fark ettim. Özür dilerim.) Sonra yüreği dayanmadl, bakamadl."

Yay ayraç içinde verilen açıklama cümlelerinde iki tür amaç olduğu düşünülmektedir. Oğuz Atay'ın başka metinlerinde görülen üst kurmaca "Ne evet ne hayır!" hikâyesinde de mevcuttur. Dolayısıyla ayraç içi cümlede üst metnin anlatıcısı yazarın ve mektubun muhatabı olan anlatıcı Dr. Akın Korkmaz'ın farklı hedefleri gözükmektedir. Yazar yani üst metnin anlatıcısı ayraç içi cümle ile hedef kitlesine ulaşacak mizahi bir anlatımı gözetirken alt metnin anlatıcısı verilen cümlelerde noktalama işaretlerinin yanlış kullanımının faili olmaktan kaçmayı düşünmektedir. Buradaki yay ayraç bilgisi hikâyenin başka yerlerinde geçen "Noktalama işaretleri benim" bilgisinden daha etkilidir. Çünkü noktalama işaretleri çok alakasız yerlerde kullanılmakta ve kamuoyunda böylesine yanlış bir işaret kullanımı küçük düşürücü bir algıya yol açmaktadır.

Ulaşılan bulgulardan hareketle metinde imla açısından büyük harf kullanımı (6) ile alıntı kelimelerin yazımına (1) ilişkin 7 örnek vardır. Metinde nokta (2), virgül (1), uzun çizgi (1), tırnak işareti (2), düzeltme işareti (1), kesme işareti (1), soru işareti (1) olmak üzere noktalamaya yönelik toplam 9 örnek bulunmaktadır.

İmla ve noktalamayla ilgili ulaşılan bulguların yanı sıra metinde biçimle ilgili olarak bir yazıda bulunması gereken paragraflara ayırma gibi şekil özelliklerine de vurgu yapılmaktadır.

Bağrım ateş gibi yandl. (satırbaşı benimdir). (Atay, 1987:93)

Yarım saat bekledim. (Satırbaşı benimdir. Çünkü M.C. 'nin satırları bitmez tükenmez aralıksı bir sel gibi aklyor.) (Atay, 1987:95)

\section{Tartışma ve Sonuç}

"Ne evet ne hayır!" hikâyesi edebî metinlerle imla ve noktalamaya yönelik farkındalık geliştirme açısından tipik bir örnektir. Bu metnin hedef kitlesi dikka- 
te alındığında imla ve noktalama için "Ne evet ne hayır"ın lise ve sonrasındaki eğitim kademesine devam edenler için uygun olacağı söylenebilir. Ancak imla ve noktalama kurallarının doğru kullanımı ilkokuldan itibaren üzerinde durulan bir konudur. Yaş ve gelişim özellikleri dikkate alınarak imla ve noktalamaya ilişkin bilgilerin edebiyatın/çocuk edebiyatının imkânlarından yararlanılarak sunulmasının faydalı olacağı düşünülmektedir. Ancak bu şekilde Türkçeye özgü imla ve noktalama kurallarının mantığı öğrenciye kavratılmış ve işlevsel bir şekilde öğretilmiş olacaktır. Yapılan çalışmalar da bu görüşü desteklemektedir (Kalfa ve Avcı 2020; Atasoy 2017; Adıgüzel 2014; Kalfa 2002).

İmla ve noktalama bilgisi, yazma becerisi ile ilişkilendirilse de okuma başta olmak üzere diğer becerilerle de yakından ilgilidir. Bir okuma metninde yazar-metin-okur üçgeninde anlam kurma sürecinde noktalama, okuru anlama taşıyan bir unsura dönüşmektedir. Aynı durum dinlemedeki anlam kurma süreci için de geçerlidir. Bir konuşmacının uygun yerde vurgu, tonlama yapabilmesi için de noktalama işaretlerinin nerede kullanılacağına yönelik bilgi sahibi olması gerekmektedir. Özkara ve İzci (2013), imla ve noktalama kurallarına uymanın okumaya yönelik olumlu tutum geliştirmede etkili olduğunu ifade etmektedir.

Bireylerin imla ve noktalamaya ilişkin yetersizliklerinin temelinde konunun beklenen düzeyde önemsenmemesinin de rolü olduğu düşünülmektedir. Ders kitaplarında yazım ve noktalama hatalarının bulunduğu bilinmektedir (Esmek 2018). Sülükçü (2018), Yazım Kılavuzu'yla çelişen veya hatalı olarak nitelenebilecek 36 madde belirlediğini dile getirmektedir. İmla ve noktalamayla ilgili özensizliğin temel sebeplerinden biri de teknolojik gelişmelerin insanlar arası iletişim şeklini değiştirmesi, sanal bir dünyada sanal sohbetlerin gerçekleştirilmesi olarak görülmektedir. Konuyla ilgili çalışmalarda da çeşitli sosyal ağlarda imla ve noktalamaya gereken önemin verilmediği hatta noktalama işaretlerinin yerini duygu simgelerine bıraktığı dile getirilmektedir (Opuş 2019; Tanrıkulu 2017; Yı1dız ve Ceran 2017; Tağa ve Ünlü 2013). Ancak Özezen (2010:236) sanal ortamlarda kullanılan, çet (chat) dili olarak adlandırılan dili, genel yazı dilinin yozlaşmış bir biçimi olarak düşünmenin doğru olmayacağını, bilişim yazınında ölçünlü dilden sapmaların hemen herkeste görüldüğünü vurgulamaktadır.

Türkçe öğretmenlerinin \%61'i, Türkçe çalışma kitaplarında yer alan noktalama işaretlerine yönelik etkinliklerin yeterli sayıda ve nitelikte olmadığı gö- 
rüşündedir (Kurudayığlu ve Dölek, 2018: 381). İlkokul öğrencilerinin çalışma kitaplarını inceleyen Akmugan (2019), öğrencilerin etkinlikleri yaparken yazım ve noktalama kurallarını dikkate almadıklarını, bu konuda yetersiz olduklarını ve öğretmenlerin konuyla ilgili geribildirimde bulunmadıklarını tespit etmiştir. Türkçe öğretmenlerinin noktalama işaretlerinin temel becerilerdeki önem ve işlevinin büyük oranda farkında olmalarına rağmen konuya ilişkin bilgi sunumunda düz anlatımı tercih etmeleri de bir çelişki olarak nitelenmektedir (Kurudayığlu ve Dölek 2018: 381).

İmla ve noktalamayla ilgili alanyazın incelendiğinde çeşitli yöntem ve tekniklerin sınandığı çalışmalarda yazım ve noktalama işaretlerini kullanım düzeyini geliştirdiğine dair bulgular mevcuttur. Öğrencilere yazım ve noktalama kurallarına uygun olarak yazma becerisi kazandırmak için yaptırılacak etkinliklerden ilki dikte çalışmalarıdır (Yangın 2002:124). Dikte uygulamaları, öğrencilerin hem yazım kurallarını hem de noktalama işaretlerini doğru kullanabilmelerinde oldukça etkili ve verimli bir öğretim etkinliğidir (Hamzadayı ve Çetinkaya 2013:140). Takım oyun turnuva tekniğinin yazılı anlatım kuralları ve noktalama işaretlerinin öğretimindeki başarı üzerinde olumlu etkiye sahip olduğu belirtilmektedir (Maden 2011: 62). Etkin öğrenme tekniklerinin (öğrenme istasyonları, top taşıma, sandviç, kart gösterme) uygulanmasının imla ve noktalama kurallarını kavratmada etkili olduğu ifade edilmektedir (Maden 2013). Sever ve Memiş (2013) de yapmış oldukları çalışmada öğrencinin merkeze alındığ süreç temelli yazma modellerinin $(4+1,6+1)$ öğrencilerin noktalama becerisini geliştirdiğini dile getirmektedir. Öğrencilere duvar yazıları hazırlatarak yazım ve noktalama işaretlerine ilişkin kuralları metin odaklı yaparak yaşayarak öğrenme firsatı sunan etkinliklerin fayda sağladığı söylenmektedir (Karakaş ve Akın 2018). Akran etkileşimine yönelik geliştirilen yazma etkinliklerinin öğrencilerin noktalama ve yazım becerilerini geliştirdiğine yönelik bulgular bulunmaktadır (Dölek ve Hamzadayı 2016). Buradan hareketle imla ve noktalama işaretlerinin öğretiminde öğrencinin sürece etkin katılımının sağlandığ durumlarda doğru ve kalıcı öğrenmenin sağlandığı söylenebilir.

İmla ve noktalamanın daha iyi nasıl kavratılacağına ve metinlerde hatasız uygulanacağına ilişkin pek çok araştırmanın yapıldığı görülmektedir. Bu çalışmada da edebî metinlerden imla ve noktalama kurallarının işlevini kavratmak 
için yararlanılabileceğini örneklemek amaçlanmıştır. Bu anlamda Oğuz Atay'ın "Ne evet ne hayır!" hikâyesi zengin bir malzeme sunmaktadır. Bulgular bölümünde metinden sadece imla ve noktalama ile ilgili kısımlar örneklenmiştir ancak metin, dilin bilinçli kullanımına ilişkin birçok ifadeye yer vermektedir.

Evlenmek istiyordum 6 aydir seviyordum sevgimi gizliyordum, tuttum sevdiğim insana bir mektup yazdım, elle gönderdim. (elden demek istiyor) (Atay, 1987: 90)

O gün (hangi gün?) pencereye çıktl, gördüm: çarşaf silken yüzünde (olamaz, 'çarşaf silkerken yüzünde' demek istedi herhalde) tatl tebessüm vardl. (Atay, 1987: 90)

Durmadan ü̧̈ ay elle (elden) posta ile mektuplar yazdım. (yolladım demek istiyor) (Atay, 1987: 90)

Sevdiğim insan da kış ayı olduğu için (Hayır, klş ayı olduğu hâlde) oturduğu evin balkonundan soğuk karda balkondan aşağ yani içeri girmemiş, gözlemiş durmuş. (Bana benzettikleri bu M.C. ile aramdaki bağıntıyı bilemeyeceğim, fakat bu sinir bozucu, bozuk ifadeli.. her neyse) (Atay, 1987: 91)

Farklı çalışmalarda bu zengin dil malzemesinin de değerlendirilmesi gerektiği düşünülmektedir.

Edebî eserler, dilin en sanatkârane örneklerini üzerinde barındırır. Okurlara yaşattığı dilsel haz, yüksek bir dil zevki kazandırır. Dilin bedii, hoş, sanatlı ve ince anlam yüklerinin mevcut olduğu örnek kullanımlar, dil zevkini inceltmekle birlikte okuru edebî eserle aynı istikamette bir dil tasarrufuna zorlar. Yazma becerilerinin kazanılmasında, gelişmesinde ve yazanın kendi kişiliği doğrultusunda özgün anlatımını, üslubunu bulmasında hem terbiye edici hem yol gösterici roller üstlenir. Bu anlamda hikâyenin ana dili eğitimi açısından oluşturacağı etki birkaç boyutlu olarak düşünülebilir. Öncelikle noktalama işaretlerinin doğru bir şekilde kullanılmadığında ortaya çıkan duygu durumu, Dr. Akın Korkmaz'ın ayraç içi ifadelerinde biriken menfi anlam yükünde görülmektedir. Yanlışın faili olarak görülme telaşı okur üzerinde anlık mizahi duygulanıma yol açsa da uzun vadede yanlış kullanımdan kaçınmak gerektiğini düşündürür, kalıcı etki bırakır. Böyle bir metinle muhatap olan okurun noktalama işaretleri kullanımında eskiye oranla daha 
hassas, daha dikkatli olacağı düşünülmektedir. Lise ve üstü seviyedeki öğrenciler için tercih edilecek bir okuma metni olan "Ne evet ne hayır!" adlı hikâye imla ve noktalama öğretiminde ders işleme sürecinde metin üzerinde gerekli düzenlemeler yapılarak uygulama örneği mahiyetinde okutulmalıdır. Başka edebî metinlerde de noktalama işaretleri kaldırılmak suretiyle meydana gelecek anlam bozuklukları veya yanlışlıkları üzerinden imla ve noktalamanın gerekliliği farklı örneklerle pekiştirilmiş olacaktır.

Türk Edebiyat tarihinde benzeri metinlere pek rastlanmamasından dolay1 Oğuz Atay’ın söz konusu hikâyesi biricik olma özelliğine sahiptir. Bu çalışmada ele alınan imla ve noktalama işaretlerinin kullanımının gerekliliği ve hassasiyeti, söz konusu hikâye metni üzerinden sunulmaktadır. Edebî eserler, okur için dilin güzel kullanımı oldukları için dil zevkinin incelmesinde ve derinleşmesinde kılavuz vazifesi görmektedir. Türkçe yazma becerisinin kazandırılması ve geliştirilmesi sırasında doğru ve güzel yazma hedefi için "Ne evet ne hayır!" uygulamalı bir örnek metin niteliğindedir. Eserin sunduğu zevkli ve eğlenceli okuma süreci, doğru, güzel ve beğenilen bir metnin olumlu sonuçlarını göstermesi veya yanlışlıkların küçük ve gülünç düşürücü sonuçlarını ortaya koyması bakımından incelenen hikâyenin kıymetinin ortada olduğu düşünülmektedir. 


\section{Kaynakça}

Adıgüzel, Muhammet Sani (2004), Türkçe Öğretim Yöntemleri, İstanbul: Yeryüzü Yayınevi.

Ağca, Hüseyin (1999), Yazılı Anlatım, Ankara: Gündüz Eğitim ve Yayıncılık Öğretmen Kitapları Serisi.

Akmugan, Ali Mürsel (2019), İlkokul 4. Sınıf Öğrencilerinin Çalışma Kitaplarında Yaptıkları Yazım ve Noktalama Hatalarının Tespiti (Erzincan Örneği), Erzincan: Erzincan Binali Yıldırım Üniversitesi Sosyal Bilimler Enstitüsü (Yayınlanmamış Yüksek Lisans Tezi).

Alpaslan Gökalp Gonca (2001), "Derslikten Günlük Yaşama Edebiyat Eğitimi”, Türkbilig Türkoloji Araştırmaları, S.1, s. 185-202.

Arastaman, Gökhan, Fidan, Öztürk İnci ve Fidan, Tuncer (2018), "Nitel Araştırmada Geçerlik ve Güvenirlik: Kuramsal Bir İnceleme”, YYÜ Eğitim Fakültesi Dergisi, C.15, S.1, s. 37-75.

Arıcı, Ali Fuat ve Ungan, Suat (2008), “İlköğretim İkinci Kademe Öğrencilerinin Yazılı Anlatım Çalışmalarının Bazı Yönlerden Değerlendirilmesi”, Dumlupınar Üniversitesi Sosyal Bilimler Dergisi, S. 20, s. 317-328.

Atasoy, Faysal Okan (2009), Türkçede Noktalama: Sorunlar-Çözümler-Teklifler. İstanbul: Marmara Üniversitesi Eğitim Bilimleri Enstitüsü (Yayımlanmış Doktora Tezi).

Atasoy, Faysal Okan (2017), "Kılavuz Kaynaklı Noktalama Sorunları ve Yazım Kılavuzundaki Eksiklikler”, Yazım Sorunları Çalışma Toplantısı 19-20 Aralık 2017, İstanbul: İstanbul Üniversitesi - Türk Dil Kurumu.

Atay, Oğuz (1987), Korkuyu Beklerken, İstanbul: İletişim Yayınları.

Atay, Selçuk (2019), “İroni İle Yoğrulmuş Bir Parodi Örneği Olarak Oğuz Atay’ın 'Ne Evet Ne Hayır'’”, Avrasya Uluslararası Araştırmalar Dergisi, C. 7, S. 17, s. 298 - 307.

Avcı, Emine (2006), İlköğretim 8. Sınıf Öğrencilerinin Yaptıkları Yazılı Anlatım Yanlışlarının İncelenmesi, Ankara: Ankara Üniversitesi Sosyal Bilimler Enstitüsü (Yayınlanmamış Yüksek Lisans Tezi).

Bağcı, Hasan (2007), Türkçe Öğretmeni Adaylarının Yazılı Anlatım Derslerine Yönelik Tutumları ile Yazma Becerileri Üzerine Bir Araştırma, Ankara: Gazi Üniversitesi Eğitim Bilimleri Enstitüsü (Yayımlanmamış Doktora Tezi).

Bağcı, Hasan (2012), "Ortaöğretim 9. Sınıf Öğrencilerinin Yazılı Anlatım Alan Bilgisi Başarı Düzeyleri Üzerine Bir Araştırma” Turkish Studies, C. 7, S. 4, s. 907-919.

Banguoğlu, Tahsin (1998), Türkçenin Grameri, Ankara: TDK Yayınları.

Beyreli, Latif, Çetindağ, Zerrin ve Celepoğlu, Ayşegül (2005), Yazılı ve Sözlü Anlatım, Ankara: PegemA Yayıncilık.

Can, Remzi (2012), Ortaöğretim Öğrencilerinin Yazılı Anlatımlarında Paragraf Düzeyinde Bağdaşıklık ve Tutarlılık. Ankara: Gazi Üniversitesi Eğitim Bilimleri Enstitüsü (Ya- 
yımlanmamış Doktora Tezi).

Çelik, Mehmet Emre (2010), İlköğretim Sekizinci Sınıf Öğrencilerinin Bilgilendirici Metin Yazma Kazanımlarına Ulaşma Düzeyleri, Samsun: Ondokuz Mayıs Üniversitesi (Yayımlanmamış Yüksek Lisans Tezi).

Demircan, Ömer (2001), Yazım: Sözel Karşıtlıkların Görsel Ayrımı, Bileşik Sözcüklerin Yazımı. Yazım ve Sorunları Bilimsel Kurultayı Bildirileri, Ankara: Dil Derneği Yayınları.

Dölek, Onur ve Hamzadayı, Ergün (2016), “Akran Etkileşimine Dayalı Yazma Etkinliklerinin 7. Sınıf Öğrencilerinin Yazılı Anlatım Becerileri Üzerindeki Etkisi”, Turkish Studies, C. 11 , S. 3, s. 965-980.

Durukafa, Gönül (1992), “Cluster Metodu”, Gazi Eğitim Fakültesi Dergisi, C. 3, S. 8, s. 83-114.

Ekinci, Çelikpazu Esra (2006), Erzurum Merkez İlçe İlköğretim 6. Sınıf Öğrencilerinin Yazılı Anlatım Becerileri Üzerine Bir Araştırma. Erzurum: Atatürk Üniversitesi Sosyal Bilimler Enstitüsü (Yayınlanmamış Yüksek Lisans Tezi).

Erdem, Hilal (2007), Dokuzuncu Sınıf Öğrencilerinin Yazım ve Noktalama Kurallarına Ulaşma Düzeyi. Ankara: Gazi Üniversitesi Eğitim Bilimleri Enstitüsü (Yayınlanmamış Yüksek Lisans Tezi).

Erkınay Hadra Kübra (2011), “Türkçe Öğretmenlerinin Yazım Kılavuzu Kullanma Konusundaki Tutum ve Görüşleri”, International Journal of Social Science, C. 4, S. 1, s. 1-24.

Esmek, Mesut (2018), İlköğretim Dördüncü Sınıf Türkçe Ders Kitabının Yazım Kuralları, Noktalama İşaretleri ve Dil Bilgisel Bazı Hususlar Açısından İrdelenmesi. Tokat: Gaziosmanpaşa Üniversitesi Eğitim Bilimleri Enstitüsü (Yayımlanmış Yüksek Lisans Tezi).

Göğüş, Beşir (1978), Orta Dereceli Okullarımızda Türkçe ve Yazın Eğitimi, Ankara: Kadığlu Matbaası.

Güneş, Firdevs (2007), Türkçe Öğretimi ve Zihinsel Yapılandırma, Ankara: Nobel Yayın.

Hamzadayı, Ergün ve Çetinkaya, Gökhan (2013), "Dikte Uygulamalarının 5. Sınıf Öğrencilerinin Yazım ve Noktalama Kurallarını Uygulama Becerilerine Etkisi”, Mersin Üniversitesi Eğitim Fakültesi Dergisi, C. 9, S. 3, s. 133-143.

Hatiboğlu, A. Necip (2003), Üniversitede Türk Dili, Ankara: Barış Yayınevi.

Kalfa, Mahir (2000), Noktalama İşaretlerinin Türkçenin Öğretimindeki Yeri ve Önemi. Ankara: Ankara Üniversitesi Sosyal Bilimler Enstitüsü (Yayımlanmamış Doktora Tezi).

Kalfa, Mahir ve Avc1, Merve (2020), “2010-2019 Yükseköğretime Geçiş Sinavlarında Noktalama İşaretlerinin Kullanımı Bilgisini Yoklayan Soruların İncelenmesi”, Ana Dili Eğitimi Dergisi, C. 8 S. 1, s. 126-134.

Kantemir, Enise (1991), Yazılı ve Sözlü Anlatım, Ankara: Ankara Üniversitesi Eğitim Bilimleri Fakültesi Yayınları. 
Karagül, Sedat (2010), İlköğretim 6-8. Sınıf Öğrencilerinin Türkçe Dersi Öğretim Programında Belirtilen Yazım ve Noktalama Kurallarını Uygulayabilme Düzeyi. İzmir: Dokuz Eylül Üniversitesi Eğitim Bilimleri Enstitüsü (Yayınlanmamış Yüksek Lisans Tezi).

Karakaş, Rezzan ve Akın Erhan (2018), "Yazım Kuralları Öğretiminde Duvar Yazılarından Yararlanma", Anemon Muş Alparslan Üniversitesi Sosyal Bilimler Dergisi, C. 6, S. 5, s. $647-654$.

Karasar, Niyazi (2006), Bilimsel Araştırma Yöntemi, Ankara: Nobel Yayın Dağıtım.

Karatay, Halit (2011), “4+1 Planlı Yazma ve Değerlendirme Modelinin Öğretmen Adaylarının Yazılı Anlatım Tutumlarını ve Yazma Becerilerini Geliştirmeye Etkisi”, Turkish Studies, C.6, S. 3, s. 1029-1047.

Kavcar Cahit, Oğuzkan, Ferhan ve Aksoy, Özlem (2002), Yazılı ve Sözlü Anlatım, Ankara: Anı Yayınc1lı.

Kavcar, Cahit, Oğuzkan, Ferhan ve Sever, Sedat (2004), Türkçe Öğretimi, Ankara: Engin Yayınevi.

Korkmaz, Zeynep (2007), Gramer Terimleri Sözlüğü, Ankara: TDK Yayınları.

Maden, Aslı (2013), Aktif Öğrenme Tekniklerinin İlköğretim 6. Sınıf Öğrencilerinin Yazım ve Noktalama Kuralları Başarısı ve Derse Karşı Tutumlarına Etkisi. Erzurum: Atatürk Üniversitesi Eğitim Bilimleri Enstitüsü (Yayımlanmış Yüksek Lisans Tezi).

Maden, Sedat (2011), "Takım Oyun Turnuva Tekniğinin Yazım Kuralları ve İşaretleri Eğitiminde Kullanımı", e - international journal of educational research, C. 2 S. 3, s. 52 - 67.

Maden, Sedat ve Maden, Aslı (2018), “Türkçe Öğretmeni Adaylarının Elektronik Sözlük ve Yazım Kılavuzu Kullanma Alışkanlıkları”, Kırıkkale Üniversitesi Sosyal Bilimler Dergisi (KÜSBD), C. 8, S. 2, s. 377-396.

Maltepe, Saadet (2006), “Türkçe Öğretiminde Yazılı Anlatım Uygulamaları İçin Bir Seçenek: Yaratıcı Yazma Yaklaşımları”, Dil Dergisi, S. 132, s. 56-66.

Opuş, Muhammed Yasir (2019), Türkçe Öğretmenlerinin Sosyal Medyadaki Dil Kullanımının Yazım (İmla) Açısından İncelenmesi: Facebook Örneği. Kütahya: Kütahya Dumlupınar Üniversitesi Eğitim Bilimleri Enstitüsü (Yayımlanmış Yüksek Lisans Tezi).

Özdemir, Emin (1991), Yazma Öğretimi, İçinde Türk Dili ve Edebiyatı Öğretimi, Eskişehir: Anadolu Üniversitesi AÖF Yayını. s. 114-149.

Özezen, Yüceol Muna (2010), “Türkçenin Ağ Ortamındaki Yazımı ve Bunun Ses Bilimsel Yapıyla Bağlantıları”, Bilig, S. 53, s. 233-256.

Özkara, Yasin ve İzci, Gülden (2013), “İlköğretim 5. Sınıf Öğrencilerinin Okumaya Yönelik Tutumları İle Noktalama İşaretlerini Uygulama Düzeyleri Arasındaki İlişkinin İncelenmesi”, Cumhuriyet International Journal of Education-CIJE, C. 2, S. 2, s. 1-9. 
Sakallı, Fatih (2011), “Tutunamayanların Hikâyeleri 'Korkuyu Beklerken””. Turkish Studies, C. 6, S. 1, s. 1713-1725.

Sever, Esra ve Memiş, Aysel (2013), "Süreç Temelli Yazma Modellerinin İlkokul Dördüncü Sınıf Öğrencilerinin Yazım-Noktalama Becerisine ve Yazma Eğilimine Etkisi”, Karadeniz Sosyal Bilimler Dergisi, C. 5, S. 9, s. 243- 259.

Sever, Sedat (2000), Türkçe Öğretimi ve Tam Öğrenme, Ankara: Anı Yayıncılık.

Sever, Sever, Kaya, Zekeriya ve Aslan, Canan (2006), Etkinliklerle Türkçe Öğretimi, İstanbul: Morpa Yayınları.

Sülükçü, Yusuf (2018), “TDK'nin Yazım Kılavuzu'ndaki Noktalama İşaretleri Hakkında Bir İnceleme ve Tespit Edilen Problemler İçin Öneriler”, TÜBAR, C. XLIII, s. 225-255.

Tağa, Tahir ve Ünlü, Süleyman (2013), "Yazma Eğitiminde Karşılaşılan Sorunlar Üzerine Bir İnceleme”, Turkish Studies, C. 8, S. 8, s. 1285-1299.

Tanrıkulu, Fatih (2017), “Türkçe Öğretmen Adaylarının Sosyal Medya Yazışmalarındaki Yazım ve Noktalama Yanlışlarının Sebepleri: Whatsapp Örneği”, International Journal of Languages' Education and Teaching, C. 5, S. 2, s. 129-143.

Tiryaki, Esra Nur (2013), "Yabancı Dil Olarak Türkçe Öğretiminde Yazma Eğitimi”, Ana Dili Eğitimi Dergisi, C. 1, S. 1, s. 38-44.

Topuzkanamış, Ersoy (2014), "Yazma Stratejileri Öğretiminin Türkçe Öğretmenliği Birinci S1nıf Öğrencilerinin Yazma Başarısına Etkisi”, TEKE, C.3, S. 2, s. 274-290.

Türkçe Sözlük, (2005), Ankara: TDK Yayınları.

Ülper, Hakan (2012), "Taslak Metinlere Öğretmenler Tarafindan Sunulan Geribildirimlerin Özellikleri”, Eğitim ve Bilim, C. 37, S. 165, s. 121-136.

Yangın, Banu (2002), Kuramdan Uygulamaya Türkçe Öğretimi, Ankara: Dersal Yayıncılık.

Yazım K1lavuzu, (2012), Ankara: TDK Yayınları.

Yıldırım, Ali ve Şimşek, Hasan (2011), Sosyal Bilimlerde Nitel Araştırma, Yöntemleri. Ankara: Seçkin Yayıncılık.

Yıldız, Derya ve Ceran, Dilek (2017), Türkçe Öğretmeni Adaylarının Yazılı Sınavlarda Yaptıkları Dil Yanlışları. İçinde Özcan Demirel ve Serkan Dinçer (Ed.), Eğitim Bilimlerinde Yenilikler ve Nitelik Arayışı. Ankara: Pegem Akademi. s. 1057-1072. 